\title{
The generic name Mediocris (Cetacea: Delphinoidea: Kentriodontidae), belongs to a foraminiferan
}

\author{
Mark D. Uhen* \\ Cranbrook Institute of Science, 39221 Woodward Avenue, Bloomfield Hills, MI 48303-0801, U.S.A.
}

Received 20 March 2006, accepted 21 March 2006

Published online 17 July 2006

Mediocris commenticius, a kentriodontid odontocete cetacean (type specimens MTMV.93.2 and MÁFI V.21681, V.21682), was recently named and described from the middle Miocene of Hungary (Kazár, 2005). The generic name Mediocris (from the Latin mediocris, or middling) was proposed in reference to the moderate size and ordinary morphology of the genus relative to other kentriodontids. Unfortunately, the generic name Mediocris is preoccupied by a fusilinacean foraminiferan (Mediocris mediocris Rozovskaya 1961), and is thus unavailable for this new taxon and the kentriodonid is in need of a new generic name.
Institutional Abbreviations. MÁFI, Magyar Állami Földtani Intézet (Geological Institute of Hungary); MTM, Magyar Természettudományi Múzeum (Hungarian Natural History Museum).

\section{References}

Kazár, E. 2005. A new kentriodontid (Cetacea: Delphinoidea) from the middle Miocene of Hungary. - Mitteilungen aus dem Museum für Naturkunde in Berlin, Geowissenschaftliche Reihe 8: 53-73.

Rozovskaya, S. E. 1961. On the systematics of the families Endothyridae and Ozawainellidae. - Paleontologicheskii Zhurnal 3: 19-21 (in Russian). 